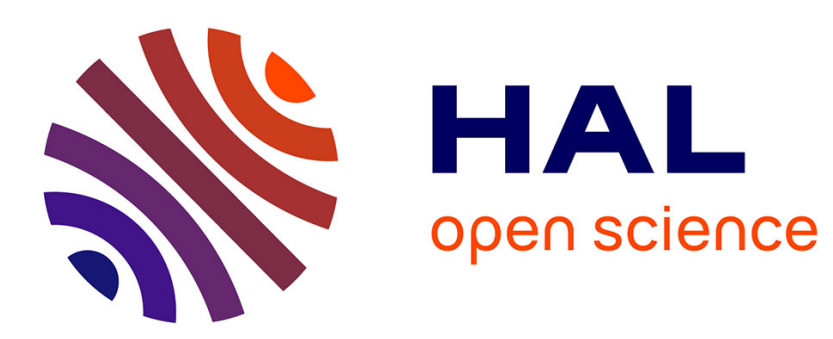

\title{
Tomographic atom probe characterization of the microstructure of a cold worked 316 austenitic stainless steel after neutron irradiation
}

Auriane Etienne, B. Radiguet, Philippe Pareige, P. Massoud, C. Pokor

\section{To cite this version:}

Auriane Etienne, B. Radiguet, Philippe Pareige, P. Massoud, C. Pokor. Tomographic atom probe characterization of the microstructure of a cold worked 316 austenitic stainless steel after neutron irradiation. Journal of Nuclear Materials, 2008, 382 (1), pp.64-69. 10.1016/j.jnucmat.2008.09.015 . hal-02107657

\section{HAL Id: hal-02107657 \\ https://hal.science/hal-02107657}

Submitted on 16 May 2019

HAL is a multi-disciplinary open access archive for the deposit and dissemination of scientific research documents, whether they are published or not. The documents may come from teaching and research institutions in France or abroad, or from public or private research centers.
L'archive ouverte pluridisciplinaire HAL, est destinée au dépôt et à la diffusion de documents scientifiques de niveau recherche, publiés ou non, émanant des établissements d'enseignement et de recherche français ou étrangers, des laboratoires publics ou privés. 


\title{
Tomographic atom probe characterization of the microstructure of a cold worked 316 austenitic stainless steel after neutron irradiation
}

\author{
A. Etienne ${ }^{\mathrm{a}, *}$, B. Radiguet ${ }^{\mathrm{a}}$, P. Pareige ${ }^{\mathrm{a}}$, J.-P. Massoud ${ }^{\mathrm{b}}$, C. Pokor $^{\mathrm{b}}$ \\ ${ }^{a}$ Groupe de Physique des Matériaux, ERT n¹000, Université et INSA de Rouen, UMR CNRS 6634, BP 12, 76801 Saint Etienne du Rouvray cedex, France \\ ${ }^{\mathrm{b}}$ EDF RED, Département MMC, Site des Renardières, 77818 Moret sur Loing cedex, France
}

\begin{abstract}
A B S T R A C T
or the first time, chemical analyses using Atom Probe Tomography were performed on a bolt made of cold rorked 316 austenitic stainless steel, extracted from the internal structures of a pressurized water reactor fter 17 years of reactor service. The irradiation temperature of these samples was $633 \mathrm{~K}$ and the irradiaon dose was estimated to $12 \mathrm{dpa}\left(7.81 \times 10^{25}\right.$ neutrons. $\left.\mathrm{m}^{-2}, E>1 \mathrm{MeV}\right)$. The samples were analysed with laser assisted tomographic atom probe. These analyses have shown that neutron irradiation has a strong ffect on the intragranular distribution of solute atoms. A high number density $\left(6 \times 10^{23} \mathrm{~m}^{-3}\right)$ of Ni-Si nriched and $\mathrm{Cr}-\mathrm{Fe}$ depleted clusters was detected after irradiation. Mo and $\mathrm{P}$ segregations at the interices of these clusters were also observed. Finally, Si enriched atmospheres were seen.
\end{abstract}

\section{Introduction}

In a pressurized water reactor (PWR), fuel assemblies and control rods are held by internal structures. These structures are constituted of vertical baffles made of 304 austenitic stainless steel (SS) fixed to baffle radial support by a large number of bolts made of cold worked (CW) 316SS. As they are located close to the reactor core, the internal structures are exposed to high dose neutron irradiation (up to $100 \mathrm{dpa}$ after 40 years of reactor service). During irradiation, the temperature of bolts is higher than $290{ }^{\circ} \mathrm{C}$ and can reach $360^{\circ} \mathrm{C}$. This irradiation results in a degradation of macroscopic properties (mainly radiation-hardening and loss of corrosion resistance) [1]. For instance, cracks were observed on CW 316 SS baffle bolts extracted from PWRs [2-5].

Since the evolution of the macroscopic properties is related to the evolution of the microstructure, understanding the microstructure evolution under irradiation is essential to predict time-of-life of internals. A large number of studies have taken an interest in the characterization of the microstructure under irradiation. On the one hand, it was shown that radiation induced segregation (RIS) at grain boundaries (GB) can contribute to the loss of corrosion resistance and could be implicated in the irradiation stress corrosion cracking (IASCC) [6-13]. Indeed, under irradiation, a permanent flux of point defects (PD) is produced towards sinks like GB. As a coupling is created between PD fluxes and solutes fluxes, it results a depletion in $\mathrm{Cr}$ and an enrichment in $\mathrm{Ni}$ at GB. On the other

\footnotetext{
* Corresponding author. Tel.: +332329158 38; fax: +3323295 5032 .

E-mail address: auriane.etienne@univ-rouen.fr (A. Etienne).
}

hand, transmission electron microscopy (TEM) observations have shown that radiation-hardening could be caused by the formation of a high number density of Frank loops (faulted loops with a Burgers vector $a_{0} / 3\langle 111\rangle$ lying in $\{111\}$ planes) and PD clusters [14-19]. Recently, it was shown that saturation of hardening at high doses could be explained by the defaulting of Frank loops [14]. However, to ensure that the yield stress evolution is only due to the Frank loops transformation, a complete characterization of the chemical microstructure is needed. Nevertheless, there is a lack of information about solute distribution in grains in these materials. $\gamma^{\prime}$ precipitation [19-20] or Ni-Si enrichment at Frank loops [21] observations using conventional transmission electron microscopy are reported in literature. The use of atomic resolution microscopy such as tomographic atom probe (TAP) has always been limited, due to the extreme brittleness of atom probe samples under the required high electric field. Today, the development of the laser assisted TAP (LATAP) allows such materials to be analysed.

The aim of this work is the application of the TAP technique to characterize chemical heterogeneities formed in a neutron irradiated CW 316SS at the atomic scale. Material characteristics and experimental procedure are given in a first part. The results obtained with the LATAP are described and compared with TEM results from literature in a second part.

\section{Experimental}

Specimens were extracted from a $15 \%$ CW 316 SS bolt coming from internals of a PWR reactor after seventeen years of reactor service. The bulk composition of the bolt, as given by the 
steelmaker, is reported in Table 1. Dimensions of the bolt are $12.95 \mathrm{~mm}$ in diameter and $69.55 \mathrm{~mm}$ in length. Samples were removed at $40 \mathrm{~mm}$ from the head of the bolt. The irradiation temperature was estimated to be $633 \mathrm{~K}$. The neutron dose was $7.81 \times 10^{25}$ neutrons. $\mathrm{m}^{-2}$ that is to say about $12 \mathrm{dpa}(\mathrm{dpa}=\sigma \times \Phi \mathrm{t}$ where $\sigma=1500$ barn is the displacement cross section and $\Phi t$ is the dose of neutrons with energy higher than $1 \mathrm{MeV}$ ).

Microstructural examinations by TEM have been performed on the PWR bolt in the EDF "hot laboratory". The dislocation microstructure of the irradiated bolt consists in interstitial Frank loops (Fig. 1(a)) and in small "black dots". The number density and the diameter of Frank loops and black dots were not measured. Most of the initial dislocation structure resulting from the cold working of the bolt has disappeared after irradiation. Cavities or bubbles were also observed (Fig. 1(b)) with a number density of $2.3 \times 10^{21} \mathrm{~m}^{-3}[22]$. Their mean diameter is about $10 \mathrm{~nm}$. Edwards et al. [20] results on a bolt extracted from Tihange PWR show the same order of magnitude of number density of cavities. These results are also in agreement with those reported by Zinkle et al. [15]. A comparison between these values can be made in Table 5. Finally, from TEM observations, no clear evidence of precipitation is observed (no chemical analyses using TEM was performed). To clarify this point, LATAP analyses were performed.

In order to exhibit the effect of neutron irradiation on solute atoms, un-irradiated CW 316SS samples were also investigated by LATAP. Specimens were obtained from another heat of CW 316SS. Its bulk composition is also given in Table 1 . As it can be seen in Table 1, no significant difference exists between the CW $316 S S$ from the bolt and the un-irradiated CW 316. Both come from intermediate carbon heats and can be compared.
All irradiated samples were cut in the shape of extremely small size rods (5 mm long and $0.1 \times 0.1 \mathrm{~mm}^{2}$ in section) in hot cells at EDF Chinon Research Centre, to limit the level of radioactivity. As far as un-irradiated material is concerned, size of rods was $10 \mathrm{~mm}$ long and $0.3 \times 0.3 \mathrm{~mm}^{2}$ in section. Rods were prepared as thin needles (end radius smaller than $50 \mathrm{~nm}$ ) by electropolishing, using a solution of $2 \%$ of perchloric acid diluted in 2-butoxyéthanol. Chemical characterization at the atomic scale was performed using the LATAP developed in the Groupe de Physique des Materiaux. The principle of this instrument is described in Refs. $[23,24]$. Analyses of brittle materials, such as irradiated austenitic stainless steels are very difficult with conventional TAP (using electric pulses). Now, the use of Laser pulses allows them to be analysed. Analyses were performed at $80 \mathrm{~K}$, using infrared femtosecond laser pulses with a pulse repetition rate equal to $2000 \mathrm{~Hz}$. The equivalent pulse fraction was estimated to $10 \%$ for both un-irradiated and irradiated samples.

\section{Results and discussion}

Analyses of the un-irradiated sample show an homogeneous distribution of solute atoms (Fig. 2). Statistical tests confirmed that all elements are randomly distributed. Thus, the mean composition of the analysed volume is representative of the matrix composition (Table 2). As it can be seen in Table 2, there is a good agreement between the measured concentrations and the bulk composition. As far as matrix composition of neutron irradiated samples (Table 2 ) is concerned, $\mathrm{Ni}$ and $\mathrm{Si}$ depletions and $\mathrm{Cr}$ enrichment are noticeable. This is due to the formation of Si enriched regions and $\mathrm{Ni}-\mathrm{Si}$ nanoclusters.

Table 1

Bulk composition of the steel used as reference sample and of the bolt steel

\begin{tabular}{|c|c|c|c|c|c|c|c|c|c|c|c|}
\hline & & $\mathrm{C}$ & $\mathrm{P}$ & $S$ & $\mathrm{Si}$ & $\mathrm{Cr}$ & $\mathrm{Ni}$ & Mn & Co & Mo & $\mathrm{Cu}$ \\
\hline \multirow[t]{2}{*}{ Reference steel } & wt $\%$ & 0.054 & 0.027 & 0.022 & 0.68 & 16.60 & 10.60 & 1.12 & 0.12 & 2.25 & 0.24 \\
\hline & at.\% & 0.25 & 0.048 & 0.038 & 1.34 & 17.70 & 10.02 & 1.13 & 0.11 & 1.30 & 0.21 \\
\hline \multirow[t]{2}{*}{ Bolt steel } & wt\% & 0.026 & 0.017 & 0.016 & 0.64 & 16.80 & 12.10 & 1.80 & $<0.05$ & 2.56 & 0.10 \\
\hline & at.\% & 0.120 & 0.030 & 0.028 & 1.27 & 17.92 & 11.44 & 1.82 & $<0.05$ & 1.48 & 0.09 \\
\hline
\end{tabular}

Values are given by the steelmaker. Values are given both in atomic and weight percents. Balance is iron.
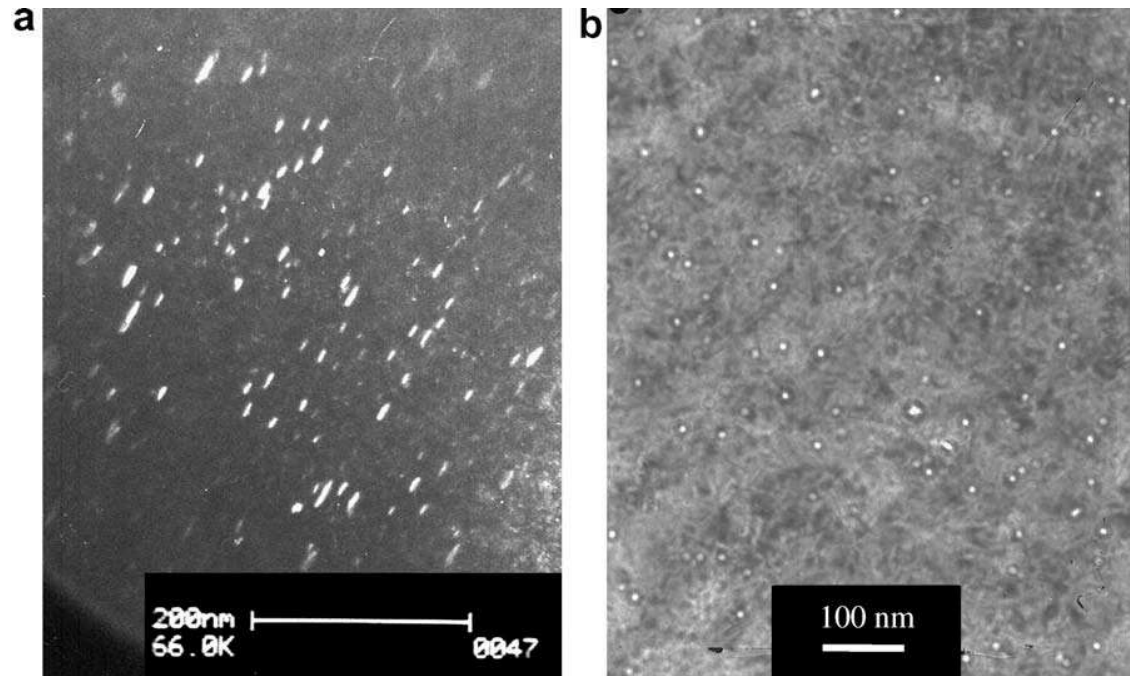

Fig. 1. (a) Imaging of Frank loops using the reciprocal lattice rod technique; (b) imaging of cavities/bubbles in a $\mathrm{CW} 316$ bolt neutron irradiated at $365{ }^{\circ} \mathrm{C}$ for a dose of $13 \mathrm{dpa}$. 

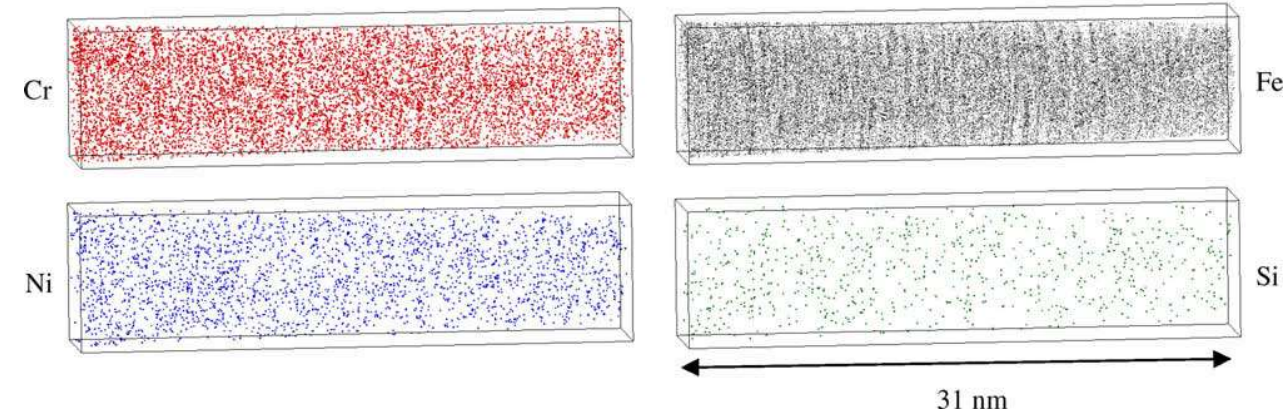

Fig. 2. 3D reconstruction of a volume of un-irradiated CW $316 \mathrm{SS}$ analysed by LATAP. Cr, Ni, Si, and Fe are represented. The volume is $8 \times 8 \times 31 \mathrm{~nm}{ }^{3}$.

Table 2

Matrix compositions (at.\%) measured by LATAP in reference material and in neutron irradiated bolt

\begin{tabular}{|c|c|c|c|c|c|c|c|c|c|c|c|}
\hline & & c & $\mathrm{P}$ & $\mathrm{Si}$ & $\mathrm{Cr}$ & $\mathrm{Ni}$ & $\mathrm{Mn}$ & Co & Mo & $\mathrm{Cu}$ & $\mathrm{v}$ \\
\hline \multirow[t]{2}{*}{ Reference sample } & at.\% & 0.27 & 0.02 & 1.57 & 18.9 & 8.5 & 1.19 & 0.14 & 0.9 & 0.13 & 0.06 \\
\hline & $2 \sigma$ & 0.03 & 0.01 & 0.07 & 0.2 & 0.2 & 0.06 & 0.02 & 0.07 & 0.02 & 0.01 \\
\hline \multirow[t]{2}{*}{ Irradiated bolt } & at.\% & 0.08 & 0.03 & 0.68 & 20.8 & 9.9 & 2.2 & 0.24 & 1.30 & 0.10 & 0.13 \\
\hline & $2 \sigma$ & 0.02 & 0.01 & 0.05 & 0.2 & 0.2 & 0.1 & 0.03 & 0.07 & 0.02 & 0.02 \\
\hline
\end{tabular}

Errors are given by the standard deviation $2 \sigma$. Balance is iron.

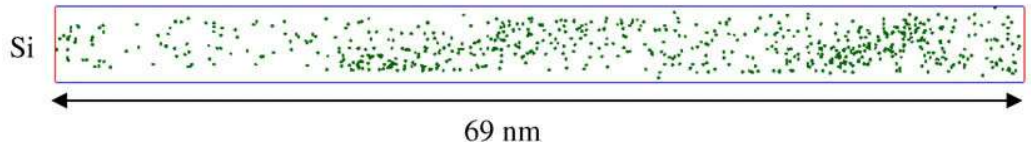

Fig. 3. 3D reconstruction of a volume of neutron irradiated bolt analysed by LATAP. Only Si is represented. The volume is $5.3 \times 5.3 \times 69 \mathrm{~nm}^{3}$. Si enriched regions are present.

Table 3

Chemical composition of the different features observed in irradiated samples

\begin{tabular}{clllrlrllll}
\hline & & $\mathrm{C}$ & $\mathrm{P}$ & $\mathrm{Si}$ & $\mathrm{Cr}$ & $\mathrm{Ni}$ & $\mathrm{Mn}$ & $\mathrm{Co}$ & $\mathrm{Mo}$ & $\mathrm{Cu}$ \\
\hline Si enriched & at.\% & 0.14 & n.s. & 4.8 & 14.5 & 15.6 & 1.75 & 0.4 & 1.4 & 0.26 \\
regions & $2 \sigma$ & 0.13 & - & 0.7 & 1.2 & 1.2 & 0.5 & 0.2 & 0.4 & 0.17 \\
& $F$ & 1.7 & - & 7.1 & 0.7 & 1.6 & 0.8 & 1.7 & 1 & 2.6 \\
Ni-Si clusters & at.\% & n.s. & 0.7 & 38.1 & 1.2 & 53.9 & n.s. & n.s. & 0.4 & 0 \\
& $2 \sigma$ & - & 0.5 & 2.8 & 0.6 & 2.9 & - & - & 0.4 & - \\
& $F$ & - & 23 & 56 & 0.06 & 5.4 & - & - & 0.3 & - \\
\hline
\end{tabular}

The enrichment factor $F$ is given by the ratio of the concentration in the feature over the matrix concentration. Errors are given by the standard deviation $2 \sigma$. Balance is iron.

(n.s.) No significant.

First, an example of Si enriched region is depicted on Fig. 3. The mean composition of these features is given in Table 3. They exhi- bit a slight enrichment factor (ratio of the concentration in the enriched region over the matrix concentration) for $\mathrm{Ni}, \mathrm{Co}, \mathrm{Cu}$ and $\mathrm{C}$. The enrichment factor is really significant for Si. A depletion in $\mathrm{Cr}$ and $\mathrm{Mn}$ is also observed in these features. These diffuse regions look like solute atmospheres. Their location at the edge of the analysed volume does not allow a quantitative estimation of their size and morphology. However their number density is of the order of $\sim 5 \times 10^{23} \mathrm{~m}^{-3}$. As the $316 \mathrm{SS}$ is $15 \%$ cold worked, these atmospheres could be attributed to segregation on the remaining dislocation network.

The second kind of features, clearly visible in the 3D reconstruction (Fig. 4), is $\mathrm{Ni}$ and $\mathrm{Si}$ enriched nanoclusters. Their number density is estimated to $6 \times 10^{23} \mathrm{~m}^{-3}$. Their average composition is given in Table 3. The average Si concentration is 40 at.\% while $\mathrm{Ni}$ concentration reaches 50 at.\% (Fig. 5). On the contrary, Fe and $\mathrm{Cr}$ concentration decrease down to 5 at.\% and 2 at.\%, respectively.
$\mathrm{Cr}$

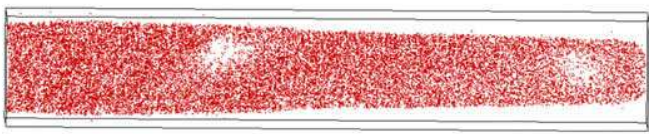

$\mathrm{Ni}$

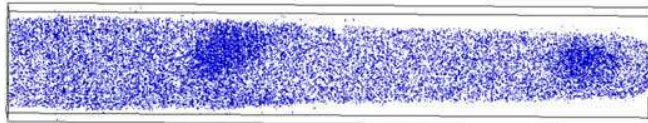

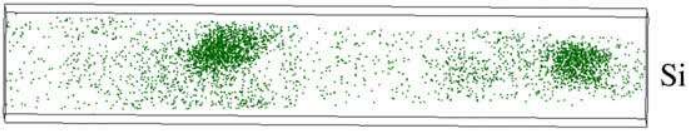

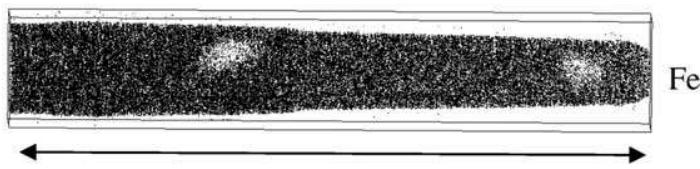

$60 \mathrm{~nm}$

Fig. 4. 3D reconstruction of a volume of neutron irradiated bolt analysed by LATAP. Cr, Ni, Si and Fe are represented. The volume is $10.4 \times 10.4 \times 60 \mathrm{~nm}{ }^{3}$. Ni-Si enriched clusters are visible. 
The Fig. 5 also reveals segregation of $\mathrm{P}$ and Mo. A reconstruction of the interface between a nanocluster and the matrix as well as a concentration profile along the interface is shown in
Fig. 6. The concentration profile perpendicular to the interface indicates that the Mo concentration reaches 25 at.\% and the P concentration about 5 at.\%. This Mo-P segregation is not observed at all

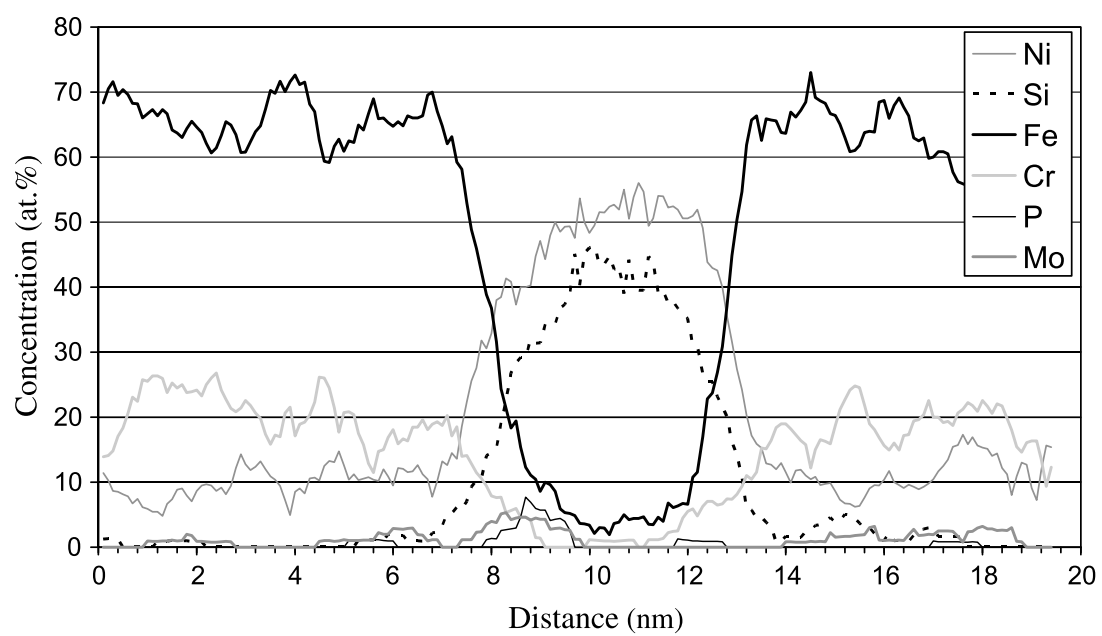

Fig. 5. Concentration profile along a Ni-Si cluster formed during neutron irradiation in CW $316 \mathrm{SS}$ bolt. Fe, $\mathrm{Ni}$, Cr, Si, Mo and P profiles are represented
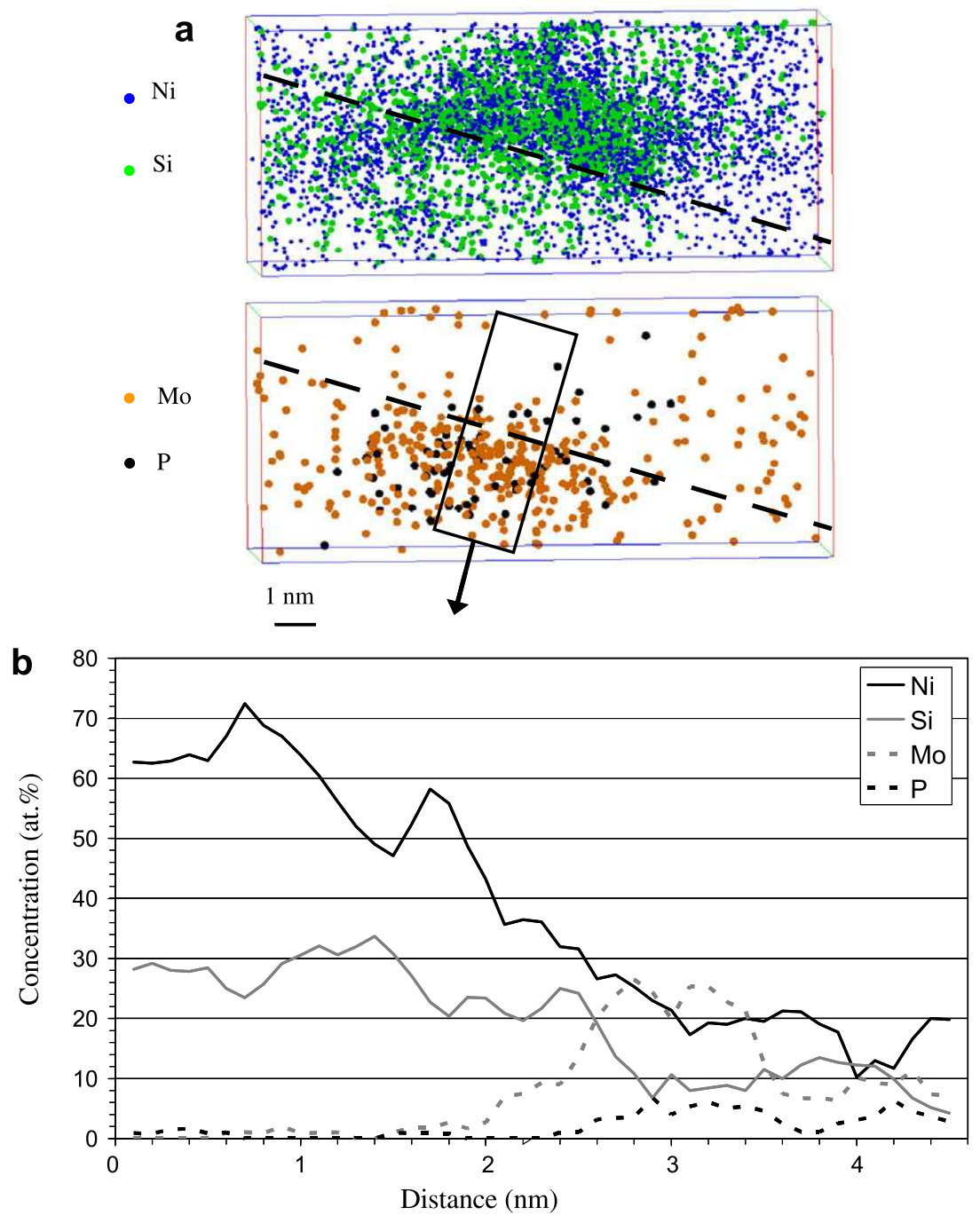

Fig. 6. (a) 3D reconstruction of a small volume of irradiated bolt showing the interface between a Ni-Si cluster and the matrix. Interface is emphasized by the dotted line. (b) The associated concentration profile through the interface is also represented (profile was plotted along the black box shown in (a)). For clarity of the image, only Ni, Si, Mo and $\mathrm{P}$ are represented. 
nanocluster interfaces. Concerning the morphology, clusters appear with an oval-shaped section (Fig. 7). The average size is $\sim 6 \times 4 \mathrm{~nm}^{2}$ in section (side view, Fig. 7) and is larger than the analysed volume section in length (top view, Fig. 7). From the average size and the number density, the volume fraction, $f_{\mathrm{v}}^{1}$, of clusters can be calculated:

$f_{\mathrm{v}}^{1}=d \times V$

where $d$ is the number density and $V$ is the volume of clusters.

Also the volume fraction, $f_{\mathrm{v}}^{2}$, can be obtained from solute concentrations (mass balance):

$f_{\mathrm{v}}^{2}=\frac{C_{0}-C_{\mathrm{m}}}{C_{\mathrm{p}}-C_{\mathrm{m}}}$

where $C_{0}, C_{m}, C_{p}$ are the solute concentrations in bulk, matrix and clusters, respectively.

Assuming that the atomic volume is the same in the matrix and in the $\mathrm{Ni}-\mathrm{Si}$ enriched phase and that the length of clusters is about the width of analysed volume (i.e., the average size of clusters is $\left.6 \times 4 \times 6 \mathrm{~nm}^{3}\right), f_{\mathrm{v}}^{1}$ and $f_{\mathrm{v}}^{2}$ can be estimated. If a large discrepancy is observed between both values, the hypothesis on the size of clusters must be rejected and re-evaluated. The results of these calculations are presented in Table 4 . It should be noticed that the average composition of analysed volumes (i.e., matrix + clusters) is different from the composition given by the steelmaker. Indeed, our experimental values are 2.53 at.\% Si and 13.57 at.\% Ni. The difference between composition given by steelmaker ( 1.27 at.\% Si and 11.44 at.\% $\mathrm{Ni}$ ) and experimental values suggests: even (i) the solute distribution is not homogeneous in the non-irradiated material or (ii) the distribution of $\mathrm{Ni}-\mathrm{Si}$ enriched clusters formed during irradiation is heterogeneous. Experiments on the non-irradiated material did not show any fluctuation of solute concentration. This dismisses the first point. Thus, in a region with $\mathrm{Ni}-\mathrm{Si}$ clusters, number density and solute levels can be slightly over-estimated. In order to compare $f_{\mathrm{v}}^{1}$ and $f_{\mathrm{v}}^{2}$, it is necessary to consider our experimental composition values. There is a good agreement between $f_{\mathrm{v}}^{1}$ and $f_{\mathrm{v}}^{2}$ calculated with $\mathrm{Ni}$ at.\%. The presence of Si enriched atmospheres can explain the small difference between $f_{\mathrm{v}}^{1}$ and $f_{\mathrm{v}}^{2}$ calculated with Si at.\%. This result shows that $6 \times 4 \times 6 \mathrm{~nm}^{3}$ is a good estimation of the cluster size.

As it is mentioned previously, the microstructure examination by TEM of this bolt has shown the presence of interstitial Frank loops, black dots and cavities. Unfortunately, number density and size of Frank loops were not measured in this work. However, dislocation loops and cavity populations in neutron irradiated 316SS
Table 4

Calculations of volume fraction, $f_{\mathrm{v}}$, from number density and size of clusters and from solute concentrations

\begin{tabular}{ll}
\hline & $f_{\mathrm{v}}(\%)$ \\
\hline From number density and average size of clusters & 8.6 \\
From $\mathrm{Si}$ at.\% & 5 \\
From Ni at.\% & 8.3 \\
\hline
\end{tabular}

have been extensively characterized in literature. Number density and size of Frank loops and cavities in 316SS, after proton or neutron irradiations, are reported in Table 5 . The number density of cavities is less than $10^{22} \mathrm{~m}^{-3}$. The average density of observed Frank loops is in the order of $10^{23} \mathrm{~m}^{-3}$, similar to Ni-Si clusters number density measured in this work. The size of Frank loops is between 7 and $12 \mathrm{~nm}$, which is the same order of the size of $\mathrm{Ni}-$ Si clusters. These correlations strongly suggest a radiation induced segregation mechanism of $\mathrm{Ni}$ and $\mathrm{Si}$ solutes on Frank loops.

Previous studies $[15,18-20,25-26]$ have already reported the presence of precipitation in irradiated 316SS. Edwards et al. [20] have found fine-scale precipitation of $\gamma^{\prime}$ precipitates and an additional phase non-identified in the shank position of a Tihange bolt irradiated at $12.2 \mathrm{dpa}$ at $616 \mathrm{~K}$. They found that $\gamma^{\prime}$ precipitates were present with a density of $\sim 0.6 \times 10^{23} \mathrm{~m}^{-3}$ and an average size of $\sim 3 \mathrm{~nm}$. According to the authors, the additional phase, present with a density of $\sim 0.2 \times 10^{23} \mathrm{~m}^{-3}$ and a larger average size, could be identified as carbide, as reported by Hashimoto et al. [18] and by Bond et al. [25]. In their study, Edwards et al., observe that both precipitations are not coinciding with voids or Frank loops. In our study the number density of Ni-Si clusters is ten times larger than what Edwards and co-workers have found and they differ from the $\gamma^{\prime}\left(\mathrm{Ni}_{3} \mathrm{Si}\right)$ stoichiometry. In [19], Edwards et al. have observed the $\mathrm{Ni}$ and $\mathrm{Si}$ segregation at Frank loops in a 316SS neutron irradiated at $\sim 13$ dpa at a temperature about $548 \mathrm{~K}$ but they did not give quantitative results of degree of segregation. On the contrary, Kenik and Hojou [21], have studied the degree of RIS at Frank loops. They observed in a nickel-stabilized austenite (USPCA), neutron irradiated up to $15 \mathrm{dpa}$ at $793 \mathrm{~K}$, that large loops above $40 \mathrm{~nm}$ exhibited a significant $\mathrm{Ni}$ and Si enrichment up to 50 and 5 at.\%, respectively. Other evidences of RIS at Frank loops were shown in ion irradiated austenitic stainless steels in [22].

Comparison between number density and size of Ni-Si clusters obtained with LATAP and number density and size of interstitial dislocation loops obtained by TEM from the literature, supports the RIS mechanism of $\mathrm{Ni}$ and $\mathrm{Si}$ solutes towards dislocation loops as already reported in $[19,21,22]$. Further investigations, as model

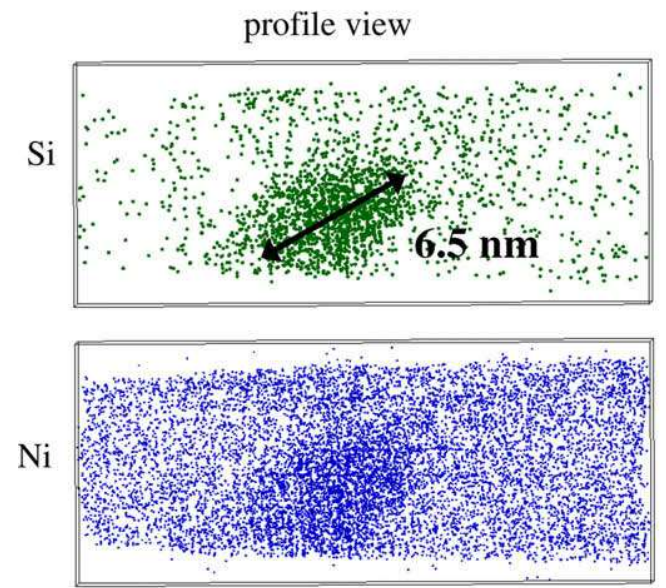

top view
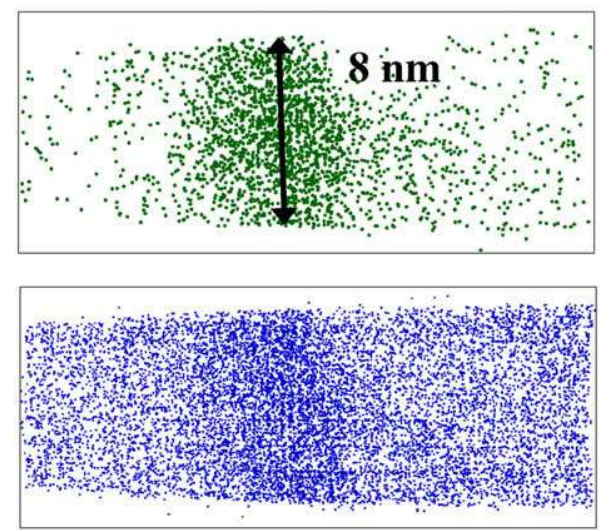

Fig. 7. Image of Ni-Si clusters analysed in a CW $316 \mathrm{SS}$ using LATAP technique. Only Si and Ni are represented. Side view and top view are depicted. 
Table 5

Measurements of dislocation loop and void characteristics in neutron or proton irradiated 316SS

\begin{tabular}{|c|c|c|c|c|c|c|c|c|c|}
\hline Ref. & Particle & $\begin{array}{l}\text { Dose } \\
\text { (dpa) }\end{array}$ & $\begin{array}{l}T \\
\left({ }^{\circ} \mathrm{C}\right)\end{array}$ & $\begin{array}{l}\text { Disloc. loop diameter } \\
(\mathrm{nm})\end{array}$ & $\begin{array}{l}\text { Disloc. loop } \\
\text { density } \\
\left(\mathrm{m}^{-3}\right)\end{array}$ & $\begin{array}{l}\text { Void diameter } \\
(\mathrm{nm})\end{array}$ & $\begin{array}{l}\text { Void } \\
\text { density }\left(\mathrm{m}^{-3}\right)\end{array}$ & $\begin{array}{l}\gamma^{\prime} \\
\text { precipitates }\end{array}$ & $\begin{array}{l}\text { Other } \\
\text { precipitates }\end{array}$ \\
\hline $\begin{array}{l}\text { This } \\
\text { work }\end{array}$ & Neutrons & 12 & 360 & n.m. & n.m. & 10 & $2.3 \times 10^{21}$ & n.o. & n.o. \\
\hline [27] & Neutrons & $\begin{array}{r}8 \\
10 \\
10 \\
20\end{array}$ & $\begin{array}{l}375 \\
375 \\
330 \\
330\end{array}$ & $\begin{array}{r}12.1 \\
12.2 \\
7.5 \\
7.4\end{array}$ & $\begin{array}{l}3.2 \times 10^{22} \\
3.2 \times 10^{22} \\
6.0 \times 10^{22} \\
4.4 \times 10^{22}\end{array}$ & $\begin{array}{l}\text { n.m. } \\
4.6 \\
\text { n.o. } \\
\text { n.o.. }\end{array}$ & $\begin{array}{l}\text { n.m. } \\
\text { few } \\
\text { n.o.. } \\
\text { n.o. }\end{array}$ & $\begin{array}{l}\text { n.o. } \\
\text { n.o. } \\
\text { n.o. } \\
\text { n.o. }\end{array}$ & $\begin{array}{l}\text { n.o. } \\
\text { n.o. } \\
\text { n.o } \\
\text { n.o }\end{array}$ \\
\hline [28] & Protons & 10 & 300 & 8.6 & $1.9 \times 10^{23}$ & n.o. & n.o. & - & - \\
\hline [20] & Neutrons & $\begin{array}{r}19.5 \\
12.2 \\
7.5\end{array}$ & $\begin{array}{l}320 \\
343 \\
333\end{array}$ & $\begin{array}{r}6.9 \\
9.5 \\
12.5\end{array}$ & $\begin{array}{l}9.2 \times 10^{22} \\
8.5 \times 10^{22} \\
1.2 \times 10^{23}\end{array}$ & $\begin{array}{l}<2 \\
8.6 \\
7.7\end{array}$ & $\begin{array}{l}<10^{20} \\
6.1 \times 10^{21} \\
1.0 \times 10^{22}\end{array}$ & $\begin{array}{l}\text { yes } \\
\text { yes } \\
\text { n.o. }\end{array}$ & $\begin{array}{l}\text { n.i. } \\
\gamma^{\prime}+\text { n.i. } \\
\text { n.o. }\end{array}$ \\
\hline [19] & Neutrons & 13.3 & 275 & 9.4 & $1.9 \times 10^{23}$ & - & - & - & RIS \\
\hline
\end{tabular}

(n.m.) Not measured, (n.o.) not observed, (-) not mentioned, (n.i.) observed but not identified.

irradiations with ions combined with TAP characterization and simulations, are needed and in progress to validate these hypotheses.

\section{Conclusion}

For the first time, the microstructure of a CW 316SS irradiated with neutrons in real PWR service conditions was characterized at atomic scale, using a 3D atom probe. Heterogeneous distribution of solute atoms after neutron irradiation has been observed. Observations revealed the presence of two kinds of features, Si atmospheres and $\mathrm{Ni}-\mathrm{Si}$ enriched clusters. The formation of these $\mathrm{Ni}-\mathrm{Si}$ clusters could be linked to the presence of Frank loops and a mechanism of RIS on dislocation loops could to explain the formation of these clusters.

\section{Acknowledgement}

The authors would like to thank EDF for providing neutron irradiated materials and the specimen preparation.

\section{References}

[1] G.E. Lucas, J. Nucl. Mater. 206 (1993) 287

[2] R. Cauvin, O. Goltrant, Y. Rouillon, E. Verzaux, A.Cazus, P. Dubuission, P. Poitrenaud, S. Bellet, in: Proceedings of International Symposium Fontevraud III, Société Française d'Energie Nucléaire, 1994, p. 54.

[3] G. Pironet, A. Heuzé, O. Goltrant, R. Cauvin, in: Proceedings of International Symposium Fontevraud IV, Société Française d'Energie Nucléaire, 1998, p. 195.

[4] O. Goltrant, R. Cauvin, D. Deydier, A. Trenty, in: Proceedings of International Symposium Fontevraud III, Société Française d'Energie Nucléaire, 1998, p. 183.

[5] I. Monnet, G.M. Decroix, P. Dubuisson, J. Reuchet, O. Morlent, in: Proceedings of International Symposium Fontevraud IV, Société Française d'Energie Nucléaire, 2002, p. 371.

[6] J.F. Williams, T.R. Mager, P. Spellward, J. Walmsley, M. Koyama, I. Suzuki, H. Mimaki, in: Eighth International Symposium on Environmental Degradation of
Materials in Nuclear Power Systems - Water Reactors, Amelia Island, FL, USA, 10-14 August 1997, p. 725.

[7] J.T. Busby, G.S. Was, E.A. Kenik, J. Nucl. Mater. 302 (2002) 20

[8] S.M. Bruemmer, E.P. Simonen, P.M. Scott, P.L. Andresen, G.S. Was, J.L. Nelson, J. Nucl. Mater. 274 (1999) 299.

[9] S.M. Bruemmer, L.A. Charlot, E.P. Simpson, in: D. Cubicciotti, E.P. Simonen, R. Gold (Eds.), Proceedings of Fifth International Symposium Environmental Degradation of Materials in Nuclear Power Systems - Water Reactors, American Nuclear Society, La Grange Park, IL, 1992, p. 821

[10] K. Fukuya, M. Nakano, K. Fujii, T. Torimaru, J. Nucl. Sci. Technol. 41 (2004) 594.

[11] G.S. Was, P.L. Andresen, J. Metals 44 (1992) 8.

[12] G.S. Was, S.M. Bruemmer, J. Nucl. Mater. 216 (1994) 326

[13] P.L. Andresen, F.P. Ford, S.M. Murphy, J.M. Perks, in: Proceedings of Fourth International Symposium on Environmental Degradation of Materials in Nuclear Power Systems - Water Reactors, Jekyll Island, GA, 1989, p. 1

[14] C. Pokor, Y. Brechet, P. Dubuisson, J.-P. Massoud, X. Averty, J. Nucl. Mater. 326 (2004) 30.

[15] S. Zinkle, P. Maziasz, R. Stoller, J. Nucl. Mater. 206 (1993) 266.

[16] J. Gan, G.S. Was, J. Nucl. Mater. 297 (2001) 161.

[17] B.H. Sencer, G.M. Bond, M.L. Hamilton, F.A. Garner, S.A. Maloy, W.F. Sommer, J. Nucl. Mater. 296 (2001) 112.

[18] N. Hashimoto, E. Wakai, J.P. Robertson, J. Nucl. Mater. 273 (1999) 95.

[19] D.J. Edwards, E.P. Simonen, S.M. Bruemmer, J. Nucl. Mater. 317 (2003) 13.

[20] D.J. Edwards, E.P. Simonen, F.A. Garner, L.R. Greenwood, B.M. Oliver, S.M. Bruemmer, J. Nucl. Mater. 317 (2003) 32.

[21] E.A. Kenik, K. Hojou, J. Nucl. Mater. 191-194 (1992) 1331.

[22] C. Pokor, J.-P. Massoud, P. Pareige, J. Garnier, D. Loisnard, P. Dubuisson, B. Doisneau, Y. Brechet, in: 12th International Conference on Environmental Degradation of Materials in Nuclear Systems - Water Reactors, The Minerals, Metals and Materials Society, Salt Lake City, 2005.

[23] D. Blavette, A. Bostel, J.M. Sarrau, B. Deconihout, A. Menand, Nature 363 (1993).

[24] B. Gault, F. Vurpillot, A. Vella, M. Gilbert, A. Menand, D. Blavette, B. Deconihout, Rev. Sci. Instrum. 77 (2006) 043705.

[25] G.M. Bond, B.H. Sencer, F.A. Garner, M.L. Hamilton, T.R. Allen, D.L. Porter, in: S.M. Bruemmer, P.Ford, G. Was (Eds.), Ninth International Conference on Environmental Degradation of Materials in Nuclear Systems - Water Reactors, The Minerals, Metals and Materials Society, Pennsylvania, 1999.

[26] P.J. Maziasz, J. Nucl. Mater. 205 (1993) 118.

[27] C. Pokor, Y. Brechet, P. Dubuisson, J-P. Massoud, A. Barbu, J. Nucl. Mater. 326 (2004) 19.

[28] B.H. Sencer, G.S. Was, M. Sagisaka, Y. Isobe, G.M. Bond, F.A. Garner, J. Nucl. Mater. 323 (2003) 18 